\title{
PARTIAL SUBSTITUTION OF NON FAT MILK SOLIDS WITH DEHULLED BLACK RICE FLOUR IN ICE MILK MANUFACTURE
}

TAWFEK, MERANDA A. ${ }^{1}$, ZAHRAT EL-OLA M. MOHAMED ${ }^{2}$ and AYAT E. RIZK ${ }^{3}$

1. Dairy Sci. \& Technol. Res., Dept. Food Technol. Res. Inst., ARC, Giza, Egypt.

2. Department of Crops Technology Research, Food Technology Research Institute, ARC, Giza, Egypt.

3. Department of Special food and nutrition, Food Technology Research Institute, ARC, Giza, Egypt.

(Manuscript received 9 March 2017 )

\begin{abstract}

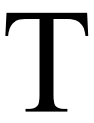
he current study was carried out to investigate some quality attributes of ice milk prepared from dehulled black rice flour. Dehulled black rice flour used as a partial substitute of skim milk powder (SMP) at ratios of zero (control), 25, 50, 75 and $100 \%$ and as a stabilizer in ice milk mixes. The chemical, physical, and rheological properties as well as sensory attributes of resultant ice milk samples were studied. Results showed that, substitution of SMP with dehulled black rice flour was significantly associated with increase in carbohydrates content, while crude protein and ash decreased significantly in ice milk mixes. Specific gravity was affected with the ratio of substitution in both mixes and resultant ice milk and therefore the overrun percent was significantly changed in the samples. Increasing the ratio of substitution with dehulled black rice flour of ice milk led to increase the values of antioxidant activity in the mixes. Ice milk mixes showed lower whipping ability with higher substitution ratios of SMP by dehulled black rice flour. Implementing dehulled black rice flour in ice milk recipes led to slightly lower acidity with higher freezing point and the product showed higher ability to melt down with increasing the ratio of dehulled black rice flour. Apparent viscosity of mixes increased significantly with rising of the substitution levels. Utilization of dehulled black rice flour in ice milk manufacture led to increase iron, zinc and potassium contents. The substitution of SMP with dehulled black rice flour up to was accepted $50 \%$ sensory attributes of ice.
\end{abstract}

Key words: skim milk powder, stabilizer, antioxidant.

\section{INTRODUCTION}

Ice milk is one of the most popular frozen desserts in Egypt. Therefore, its production has been recently increased markedly. The nutritive value of ice milk is based not only on the nutritive value of milk, but also increased digestibility and additives which were added during the manufacture of ice milk Arbuckle (1986). Consumer acceptance of ice cream depends largely on its structure, textural quality, resistance to melting and flavor, ice milk has been also used to deliver probiotic bacteria to consumers Kebary and Hussein (1997) and Fayed et al., (2012). 
In Egypt and according to the Egyptian Standard 1185-3/2005, the fat content of ice milk must not less than $3 \%$. The milk fat can be partially or totally replaced by plant oils.

Consumers are becoming increasingly aware of and looking for foods with health benefits. Joint efforts between the food industry and the academic sector have led to studies on changes in ice cream formulations Cadena and Bolini (2011).

Rice (Oryza sativa L.) is a widely consumed food. There are many special cultivars of rice that contain colour pigments, such as black, red and brown. However, in the recent years pigmented rice varieties have received increased attention from the researchers and consumer preferences have shifted towards pigmented types having high nutritional properties. Li et al., (2016).

Many people assume this rice as a panacea of many culinary diseases because of its high nutritive value and curative effect. This rice is supposed to enhance the longevity of life, hence it is also known as long life rice. Kong and Lee (2010)

Black rice special and medicinal values are truly stunning even today with all of our medical knowledge and tools. Thus black rice is a kind of food that can make us healthy and save our life. Black rice is a whole grain and nowadays, whole grain is categorized as one of the potent functional food sources since it contains high amounts of phenolic compounds, especially anthocyanins in pericarp Abdel-Aal, et al., (2006). Black rice has high nutritional value and it contains the highest levels of anthocyanin. Its dark purple color is primarily due to its anthocyanin content, which is higher by weight than that of other coloured grains. Black rice has a number of nutritional advantages over common rice, such as a higher content of protein, vitamins and minerals, although the latter varies with cultivar and production location Suzuki et al., (2004).Red and black rice are used as food colorants in cakes, breads, ice cream and liquor and as functional foods due to antioxidant activity conferred by high levels of polyphenols Abdel-Aal et al., (2006).

The present study aims to produce ice milk substituted with different percentages of black rice flour in relation to physical, chemical and sensory characteristics of the final product. 


\section{MATERIALS AND METHODS}

\section{Materials}

Fresh cow's milk was obtained from the Faculty of Agriculture, Cairo University, Giza, Egypt. Skim milk powder (SMP) made in USA and vanilla were obtained from the local market. Commercial grade can sugar was purchased from Sugar and Integrated Industries Company, Giza, Egypt. High viscosity carboxymethyl cellulose (CMC) produced by TIC gums, MD,USA was used as a stabilizer.

Black rice (Oryze sativa L.) obtained from Rice Research and Training Center (RRTC) at Sakha, experimental station Kafr El-sheikh Governorate, Egypt during the season of 2015.

\section{Experimental procedures}

Preparation of powdered black rice

Raw rice grain samples were dehulled to obtain the dehulled black rice then milled to obtain its flour by laboratory mill (National, Japan), and then sieved through a $0.1 \mathrm{~mm}$ mesh sieve. The resultant flour was packed in polyethylene bags and stored in refrigerator until used.

The composition of dehulled black rice flour and other ingredients used in ice milk are presented in Table (1),

Table 1. Composition of dehulled black rice flour and other ingredients used in preparation of ice milk

\begin{tabular}{|l|l|l|l|}
\hline Property & Fresh cow's milk & $\begin{array}{l}\text { skim milk powder } \\
(\text { SMP) }\end{array}$ & $\begin{array}{l}\text { dehulled black rice } \\
\text { flour }\end{array}$ \\
\hline Total solids\% & $12.53 \pm 0.21$ & $96.2 \pm 0.14$ & $88.76 \pm 0.17$ \\
\hline Fat\% & $4.00 \pm 0.16$ & $0.80 \pm 0.06$ & $2.30 \pm 0.11$ \\
\hline protein\% & $2.89 \pm 0.14$ & $33.4 \pm 0.24$ & $8.20 \pm 0.14$ \\
\hline ash\% & $0.663 \pm 0.12$ & $7.90 \pm 0.28$ & $1.70 \pm 0.06$ \\
\hline Crude fiber (\%) & Free & Free & $2.30 \pm .16$ \\
\hline pH values & $6.40 \pm 0.17$ & $6.6 \pm 0.25$ & $7.10 \pm 0.20$ \\
\hline lactose or carbohydrate * & $4.98 \pm 0.41$ & $54.10 \pm 0.20$ & $74.26 \pm 0.33$ \\
\hline Antioxidant activity(\%)** & ND & ND & 41.86 \\
\hline Fe (mg/100g) & ND & ND & 3.99 \\
\hline Zn (mg/100g) & ND & ND & 2.50 \\
\hline P (mg/100g) & ND & ND & 320 \\
\hline K (mg/100g) & ND & ND & 368 \\
\hline Ca (mg/100g) & ND & ND & 18.80 \\
\hline
\end{tabular}

$*$ : Calculated by difference.

**: percent reduction of antioxidant activity of DPPH.

Values are means of three replicates $\pm \mathrm{SD}$

ND: not determined 


\section{Manufacture of ice milk}

Mixes of ice milk batches were prepared from the aforementioned ingredients with quantities calculated as shown in Table (2). The control mix was standardized to contain $6 \%$ fat, $11 \%$ SNF, $14 \%$ sugar and $0.2 \%$ CMC. Pregelatinized dehulled black Rice flour was used to replace $25,50,75$ and $100 \%$ of SMP added to raise the solids not fat (SNF) in the mix as shown in Table (2). Mixes were heat treated up to $85 \pm 1{ }^{\circ} \mathrm{C}$ for about $30 \mathrm{~s}$., then rapidly cooled to $5 \pm 1^{\circ} \mathrm{C}$ and aged at the same temperature for $24 \mathrm{~h}$. After ageing, $0.01 \%$ vanilla powder was directly added to the mixes before frozen in horizontal batch freezer (Taylor Co. USA). The frozen ice milk was drawn in plastic cups $(120 \mathrm{ml})$ and hardened at $-26^{\circ} \mathrm{C}$ for $24 \mathrm{~h}$ before analyses. All treatments were of three replicates.

\section{Analytical methods}

\section{- Chemical analyses}

Moisture, crude protein, crude fiber, fat, and ash contents were determined according to the methods outlined in AOAC (2007). Total carbohydrates of dehulled black rice flour and ice milk mixes were calculated by differences as described by Ceirwyn (1995). Titratable acidity was determined in duplicate by titration with $0.1 \mathrm{~N}$ $\mathrm{NaOH}$ calculated as lactic acid percent according to Richardson (1986).

\section{Physical analyses}

The specific gravity of ice milk mixes and the resultant ice milk were determined as described by Winiori $(1958)$ at $20^{\circ} \mathrm{C}$. The freezing point of the mixes was measured as described in FAO Laboratory manual (1977). The pH values were measured using a digital laboratory pH meter (HI 93 1400, Hanna instruments) with glass electrode. Mineral contents were determined as described by Hankinson (1975) using Atomic absorption spectrophotometer NO.3300 (PerkinElmer, US instrument Division Norwalk, CT, USA.).The overrun values of ice milk were calculated mentioned by Marshall et al., (2003). Melting resistance of the resultant ice milk as samples was determined as mentioned by Segall and Goff (2002).Determination of viscosity was determined using a coaxial rotational viscometer (Rheotest II, Medingen, Germany) at shear rates ranging from 3.0 to 1312 $\mathrm{s}^{-1}$. The measuring device (S1) was used with a sample volume of $30 \mathrm{ml}$ per run. All samples were adjusted to $20 \pm 1{ }^{\circ} \mathrm{C}$ before loading in the viscometer device. Apparent viscosity was calculated at shear rate of $48.6 \mathrm{~s}^{-1} .(\mathrm{RPM}=20$, Spindle $=21)$ .Hardness of frozen samples were examined by adapting the method recommended by Bourne and Comstock (1986). Antioxidants activity as indicator of antioxidant contents were determined according to Olivera et al., (2006). 


\section{Sensory evaluation}

Samples of ice milk after $24 \mathrm{~h}$. of hardening at $-26^{\circ} \mathrm{C}$ were judged by a panel of 10 judges selected on the basis of their consistency in scoring. The samples were scored for flavour (out of 45 point), body and texture (out of 35 point), melting properties( out of 10 point) and colour (out of 10 point) as suggested by Arbuckle (1986).

\section{Statistical analysis}

The obtained data from physicochemical properties and sensory evaluation were exposed to analysis of variance. Duncan's multiple range tests at $(P \leq 0.05)$ level was used to compare between means Steel and Torrie (1997).

Table 2. Formulation of one $\mathrm{kg}$ ice milk containing different ratios of dehulled black rice flour.

\begin{tabular}{|l|c|c|c|c|c|}
\hline \multirow{2}{*}{ Ingredients } & \multicolumn{5}{|c|}{ Substitution level (\%) of skim milk powder with } \\
& \multicolumn{5}{|c|}{ dehulled black rice flour } \\
\cline { 2 - 6 } & Control & 25 & 50 & 75 & 100 \\
\hline \multirow{2}{*}{ Fresh cow's milk (g) } & 814.08 & 816 & 816 & 816 & 816 \\
\hline \multirow{2}{*}{ skim milk powder (g) } & 33.92 & 25.25 & 17 & 8.5 & - \\
\hline \multirow{2}{*}{ Sucrose or can sugar (g) } & 150 & 150 & 150 & 150 & 150 \\
\hline \multirow{2}{*}{ CMC (g) } & 2 & - & - & - & - \\
\hline \multirow{2}{*}{ Black rice (g) } & - & 8.5 & 17 & 25.5 & 34 \\
\hline Total (g) & 1000 & 1000 & 1000 & 1000 & 1000 \\
\hline
\end{tabular}

Vanilla was added at $0.1 \mathrm{~g} / \mathrm{kg}$,

\section{RESULTS AND DISCUSSION}

\section{Properties of ice milk mixes}

The chemical characteristics of ice milk mixes with dehulled black rice flour as a substitution of skim milk powder (SMP) is shown in Table (3). 
Table 3. Chemical composition (\%) of ice milk mixes with dehulled black rice flour as a substitution of skim milk powder (SMP).

\begin{tabular}{|l|c|c|c|c|c|}
\hline \multirow{2}{*}{ Property \% } & \multicolumn{5}{|c|}{ Substitution level (\%) of skim milk powder with dehulled black rice flour } \\
\cline { 2 - 6 } & Control & 25 & 50 & 75 & 100 \\
\hline Total solids & $29.05 \pm 0.63^{\mathrm{b}}$ & $30.55 \pm 0.16^{\mathrm{a}}$ & $30.63 \pm 0.07^{\mathrm{a}}$ & $30.67 \pm 0.18^{\mathrm{a}}$ & $30.73 \pm 0.12^{\mathrm{a}}$ \\
\hline Fat & $4.15 \pm 0.07^{\mathrm{a}}$ & $4.16 \pm 0.08^{\mathrm{a}}$ & $4.18 \pm 0.11^{\mathrm{a}}$ & $4.20 \pm 0.042^{\mathrm{a}}$ & $4.21 \pm 0.03^{\mathrm{a}}$ \\
\hline Total protein & $4.49 \pm 0.056^{\mathrm{a}}$ & $4.393 \pm 0.19^{\mathrm{ab}}$ & $4.194 \pm 0.14^{\mathrm{abc}}$ & $3.97 \pm 0.04^{\mathrm{bc}}$ & $3.76 \pm 0.16^{\mathrm{c}}$ \\
\hline Ash & $0.994 \pm 0.00^{\mathrm{a}}$ & $0.993 \pm 0.01^{\mathrm{a}}$ & $0.993 \pm 0.02^{\mathrm{a}}$ & $0.992 \pm 0.01^{\mathrm{a}}$ & $0.992 \pm 0.00^{\mathrm{a}}$ \\
\hline Carbohydrate* & $19.42 \pm 0.51^{\mathrm{b}}$ & $21.01 \pm 0.10^{\mathrm{a}}$ & $21.26 \pm 0.10^{\mathrm{a}}$ & $21.51 \pm 0.07^{\mathrm{a}}$ & $21.77 \pm 0.26^{\mathrm{a}}$ \\
\hline
\end{tabular}

* Carbohydrate content was determined by difference

Values are means of three replicates $\pm S D$, numbers in the same raw, followed by the same letters, are not significantly different at 0.05 level.

Data in Table (3) indicated that TS significantly increased in dehulled black rice flour ice milk mixes compared to control (29.05\%). This significant increase in TS may reflected by the corresponding increase in total carbohydrates. One of the parameters that directly affects the quality of foods is total solid matters particularly, ice milk. It is directly related to ice crystal size distribution. Variations in solids content of just a few percent greatly influences ice crystal growth. If these are in excess then curded texture could result, while low contents resulted in ice crystal formulation and coarse texture Amiri et al., (2014). Fat was not significantly affected with substitution Even though, there was a slight increase in fat of dehulled black rice flour ice milk mixes relative to control .Data also revealed that there was a slight decrease in ash content of black rice ice milk mixes and this may be due to that the black rice has lower ash value compared to SMP as shown in Table (1). From the same Table, total protein of dehulled black rice flour ice milk mixes decreased significantly via increasing the substitution ratio of dehulled black rice flour. Protein affects the quality of the ice milk where it provides a slight flavor, water holding and also affects the formation of size of air cells. Protein interacts at the oil water interface during homogenization to stabilize the fat emulsion and during freezing, proteins function to encapsulate the air cells and control destabilization of fat Liou (2006).On the other hand, dehulled black rice flour ice milk mixes had significantly higher carbohydrate content compared to control this is due to the lower protein and higher carbohydrate content of dehulled black rice flour compared to SMP. Increasing the sugar content of ice milk causes a smooth texture, because it lowers the freezing point, the amount of unfrozen material is increased, increased viscosity and free water contents declined Marshall and Arbuckle (1996). 
These results are agreement with Awad (2007) who reported total protein and carbohydrates content were significantly affected by adding rice flour as partial substitution of SMP.

Data in Table (4) showed that the effect of dehulled black rice flour substitution of skim milk powder (SMP) on some properties of ice milk mixes.

Table 4. Physicochemical properties of ice milk mixes with dehulled black rice flour as a substitution of skim milk powder (SMP).

\begin{tabular}{|c|c|c|c|c|c|}
\hline \multirow[b]{2}{*}{ Property } & \multicolumn{5}{|c|}{ Substitution level $(\%)$ of skim milk powder with dehulled black rice flour } \\
\hline & Control & 25 & 50 & 75 & 100 \\
\hline Acidity (\%) & $0.46 \pm 0.01^{\mathrm{a}}$ & $0.244 \pm 0.01^{\mathrm{b}}$ & $0.244 \pm 0.02^{\mathrm{b}}$ & $0.236 \pm 0.01^{b}$ & $0.222 \pm 0.03^{b}$ \\
\hline $\mathrm{pH}$ value & $6.34 \pm 0.02^{\mathrm{e}}$ & $6.5 \pm 0.01^{\mathrm{d}}$ & $6.56 \pm 0.01^{c}$ & $6.62 \pm 0.01^{\mathrm{b}}$ & $6.70 \pm 0.03^{a}$ \\
\hline $\begin{array}{l}\text { Freezing point } \\
\left(-{ }^{\circ} \mathrm{C}\right)\end{array}$ & $-2.43 \pm 0.04^{c}$ & $-2.37 \pm 0.014^{c}$ & $-2.20 \pm 0.02^{b}$ & $-2.15 \pm 0.03^{\mathrm{ab}}$ & $-2.10 \pm 0.03^{\mathrm{a}}$ \\
\hline Specific gravity & $1.1390 \pm 0.02^{\mathrm{a}}$ & $1.1330 \pm 0.00^{\mathrm{a}}$ & $1.1298 \pm 0.00^{\mathrm{a}}$ & $1.1275 \pm 0.02^{\mathrm{a}}$ & $1.1241 \pm 0.00^{\mathrm{a}}$ \\
\hline $\begin{array}{l}\text { Antioxidant } \\
\text { activity (\%) }\end{array}$ & $3.12 \pm 0.03^{e}$ & $5.28 \pm 0.11^{\mathrm{d}}$ & $7.88 \pm 0.14^{c}$ & $11.10 \pm 0.14^{b}$ & $13.85 \pm 0.08^{a}$ \\
\hline
\end{tabular}

Values are means of three replicates $\pm S D$, numbers in the same raw, followed by the same letters, are not significantly different at 0.05 level.

Results indicated that the $\mathrm{pH}$ values significantly increased and titratable acidity values significantly decreased with dehulled black rice flour substitution in ice milk formula. $100 \%$ had the highest $\mathrm{pH}$ values relative to other treatments (6.7) .These differences in acidity and $\mathrm{pH}$ values of ice milk mixes could be due to the lower acidity and higher $\mathrm{pH}$ values of dehulled black rice flour as compared to SMP in Table (1). This could be due to the increase of TS, where the acidity of ice milk is affected by solid matters. Specific gravity is the ratio of the density of water at $20{ }^{\circ} \mathrm{C}$ component or a material compared to the density of water and varies with varying mix composition. Specific gravity of ice milk mixes was gradually decreased with adding dehulled black rice flour in the recipes. Freezing point of ice milk mixes is highly dependent directly on, the soluble components like sweeteners and indirectly to, the ratio of fat and protein in the mix. Freezing points of ice milk mixes was significantly affected with adding dehulled black rice flour. Where, the mixes showed higher freezing points with increasing substitution of SMP with dehulled black rice flour compared to control. Freezing point is affected by the amount, type, and molecular weight of the solutes in the mix. Marshall et al., (2003). The obtained 
results are in line with Awad (2007). From the same Table, Incorporation of dehulled black rice flour showed significant higher values of antioxidant activity than control. Increasing the ratio of substitution with dehulled black rice flour of ice milk increased the values of antioxidant activity in treated mixes. This results due to higher antioxidant of dehulled black rice flour than SMP. Viscosity is an important characteristic in that a specific viscosity amount is required for achieving desirable whipping ability and retaining of air bubbles Tarkashvand (2005). Substitution with dehulled black rice flour was significantly affected the apparent viscosity of ice milk mixes (Fig.1). Data indicated that the use of dehulled black rice led to increase the viscosity of the ice milk mixes. Values of apparent viscosity significantly increased with adding dehulled black rice flour in the formula being highest in treatment 100 with $100 \%$ SMP substitution. The differences in flow time and viscosity values of control and treatments with dehulled black rice flour could be due to the differences in composition of both materials. Dehulled black rice flour contains a high amount of starchy material which able to gelatinize and therefore, increase the viscosity under die processing conditions of ice milk mix. The higher ratio of starch in dehulled black rice flour may adsorb and bind greater amount of free water and therefore increases the viscosity and flow time of mix when compared to substituted SMP which contains high amount of lactose. The results an in same manner with Awad (2007) who found an increase in viscosity of ice cream mixes with adding rice flour powder.

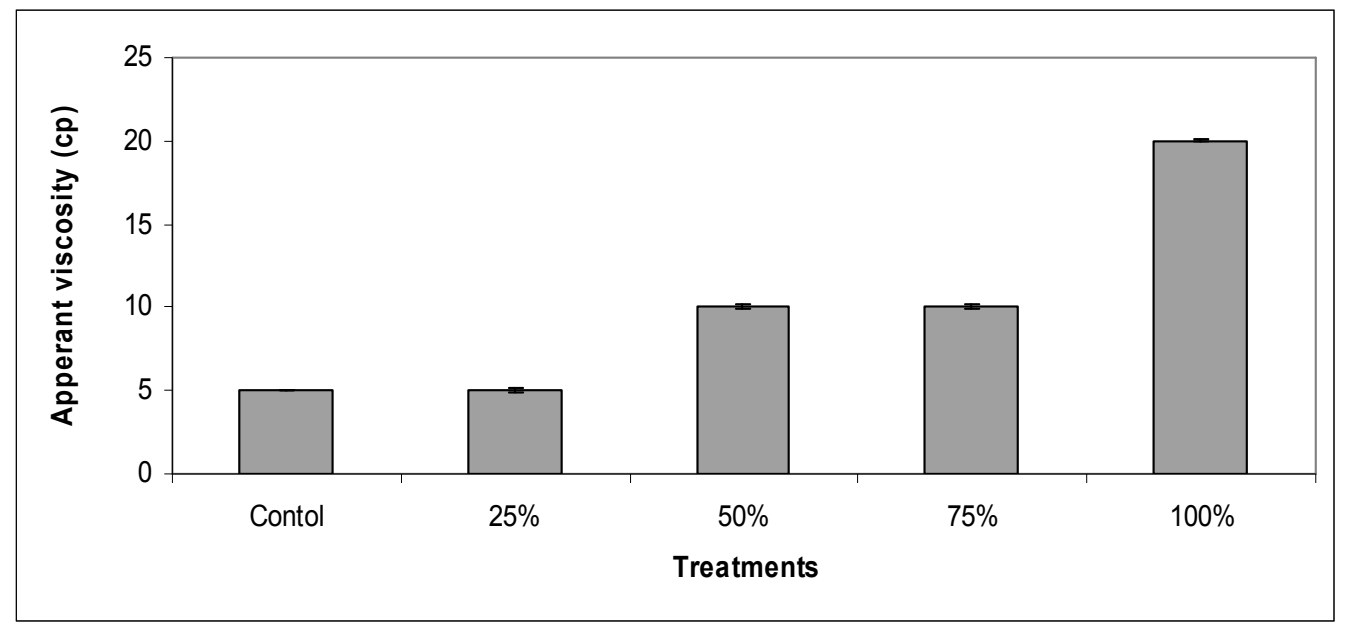

Fig. 1. Apparent viscosity of ice milk mixes fortified with different ratios of dehulled black rice flour. 


\section{Minerals content}

Milk and milk products are considered as poor sources of Fe and therefore, fortification of milk products with natural Fe source would be a helpful tool. Results in Table (5) showed that the iron content of substituted milk with dehulled black rice flour varied between $0.19-0.88(\mathrm{mg} / 100)$ compared to $0.04(\mathrm{mg} / 100)$ in control treatment. Adding dehulled black rice flour to ice milk blends was also accompanied by high level of potassium content due to the high content of this element in black rice flour ( $368 \mathrm{mg} / 100 \mathrm{~g}$ ). Addition of dehulled black rice flour to ice milk mix slightly increased the zinc content of resultant ice milk. On the other hand, substitution with black rice flour in ice milk recipes led to decrease the content of calcium in the resultant product which could be attributed to the low contents of these elements in dehulled black rice flour

Table 5. Mineral content of ice milk mixes with dehulled black rice flour as a substitute of skim milk powder (SMP).

\begin{tabular}{|l|c|c|c|c|c|}
\hline \multirow{2}{*}{$\begin{array}{l}\text { Property } \\
(\mathrm{mg} / \mathbf{1 0 0})\end{array}$} & \multicolumn{5}{|c|}{ Substitution level (\%) of skim milk powder with dehulled black rice flour } \\
\cline { 2 - 6 } & Control & 25 & 50 & 75 & 100 \\
\hline $\mathrm{K}$ & 150 & 170 & 200 & 220 & 260 \\
\hline $\mathrm{Ca}$ & 119 & 116.8 & 115.6 & 114.00 & 111.8 \\
\hline $\mathrm{P}$ & 91 & 100 & 120 & 150 & 170.8 \\
\hline $\mathrm{Fe}$ & 0.04 & 0.19 & 0.32 & 0.59 & 0.88 \\
\hline $\mathrm{Zn}$ & 0.3 & 0.4 & 0.65 & 0.86 & 1.02 \\
\hline
\end{tabular}

\section{Whipping ability}

Whipping ability determines the ease with which air be incorporated into ice milk mix. The whipping ability of ice milk mixes with dehulled black rice flour as a substitute of added SMP is illustrated in Fig. (2). All treatments showed higher whipping ability at beginning time of whipping. As whipping continued, the increase in volume diminished, indicating decreased whipping ability. Treatments 25and50 showed slight better whipping ability after $5 \mathrm{~min}$ and were so close to control after 10 min of whipping. This means that the air was incorporated into the mix of treatments 25 and50 was slightly faster than that of control up to $10 \mathrm{~min}$. This trend became slightly opposite for both treatments after 15 and $20 \mathrm{~min}$. On the other hand, treatments 75and 100 showed lower whipping ability compared to control or treatments 25 and50 with dehulled black rice flour. The main factor that affects the whipping ability may be the mix viscosity which has inhibitory effect on whipping ability. The air was incorporated slowly with higher viscosity values and reaches to the maximum rate in shorter time as the ratio of added dehulled black rice flour increased. 


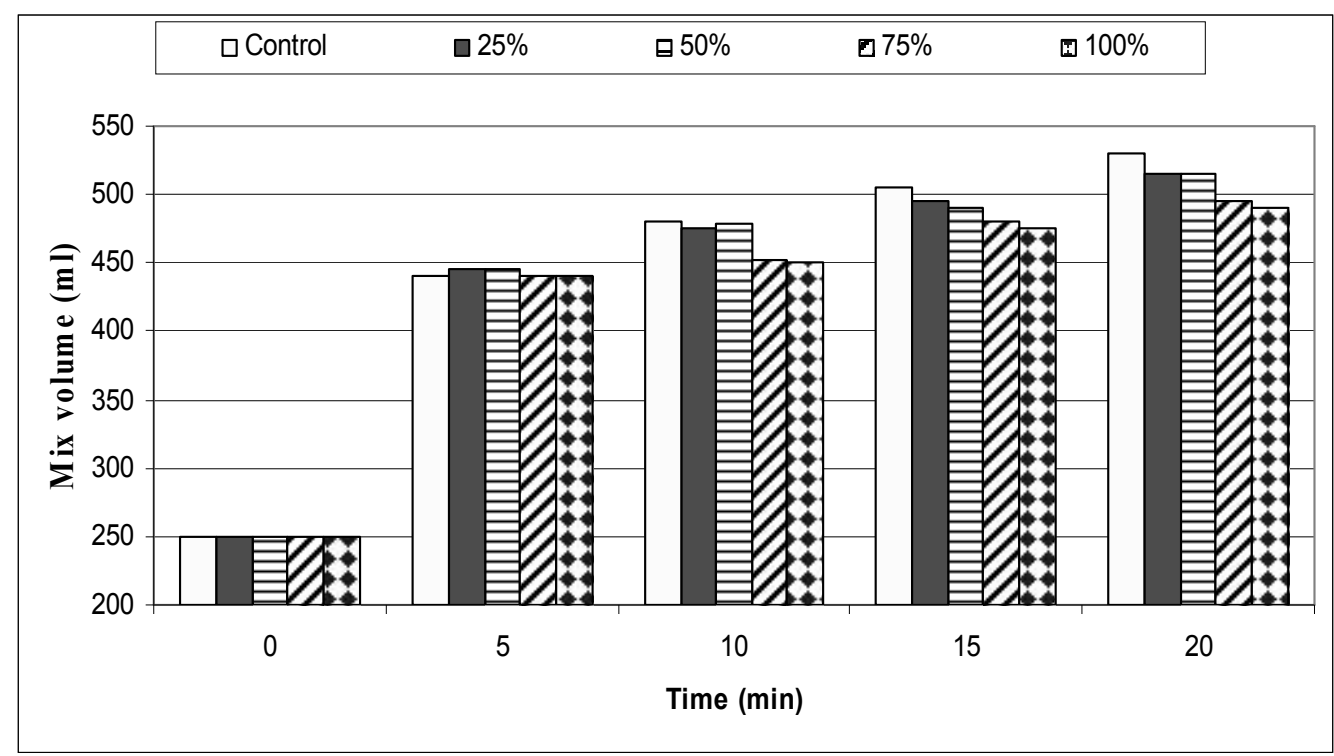

Fig. 2. Whipping ability of ice milk mixes with dehulled black rice flour as a partial substitute of skim milk powder in the formula.

\section{Properties of ice milk samples}

Effect of dehulled black rice flour as a substitute of SMP on some properties of the resultant ice milk is presented in Table (6). Data indicated that the specific gravity of the ice milk was increased in the dehulled black rice flour ice milk treatments compared to control .Specific gravity depends on the formula components as well as the ability of mix to retain the air cells in ice milk system.

Table 6. Effect of dehulled black rice flour substitution of skim milk powder (SMP) and stabilizer on properties of resultant ice milk.

\begin{tabular}{|c|c|c|c|c|c|}
\hline \multirow[b]{2}{*}{ Property } & \multicolumn{5}{|c|}{ Substitution level (\%) of skim milk powder with dehulled black rice flour } \\
\hline & Control & 25 & 50 & 75 & 100 \\
\hline Specific gravity & 0.684 & 0.691 & 0.702 & 0.712 & 0.733 \\
\hline Overrun (\%) & $67.40 \pm 0.84^{\mathrm{a}}$ & $65.89 \pm 0.63^{b}$ & $65.01 \pm 0.13^{b}$ & $64.81 \pm 0.13^{\mathrm{b}}$ & $60.89 \pm 0.04^{c}$ \\
\hline $\begin{array}{l}\text { Freezing time } \\
\text { (min.) }\end{array}$ & $17.00 \pm 0.28^{a}$ & $16.2 \pm 0.11^{\mathrm{b}}$ & $15.50 \pm 0.14^{c}$ & $15.50 \pm 0.14^{c}$ & $15.0 \pm 0.14^{d}$ \\
\hline \multicolumn{6}{|l|}{$\begin{array}{l}\text { Melting } \\
\text { resistance loss \% } \\
\text { after min) }\end{array}$} \\
\hline 15 & 4.10 & 4.08 & 4.0 & 3.8 & 3.6 \\
\hline 30 & 23.3 & 19.91 & 17.51 & 16.71 & 15.81 \\
\hline 45 & 40.52 & 37.01 & 36.00 & 32.81 & 31.11 \\
\hline 60 & 80.50 & 79.95 & 79.90 & 79.88 & 79.8 \\
\hline 75 & 97.90 & 97.80 & 97.62 & 97.52 & 97.50 \\
\hline Hardness & 9.20 & 9.25 & 9.3 & 9.71 & 9.95 \\
\hline
\end{tabular}

Values are means of three replicates $\pm S D$, numbers in the same raw, followed by the same letters, are not significantly different at 0.05 level. 
The amount of air added to ice milk is known as overrun. Overrun percent in ice milk was significantly decreased by dehulled black rice flour as a SMP substitution changes in overrun percentages of ice milk samples with dehulled black rice flour as a substitute of SMP could be related to the different viscosity values. A. certain level of viscosity in ice milk mix is needed for, proper whipping and retention of air cells. Beyond that level with higher or lower viscosity values, the mix will be poor in whipping and retention of air cells, so the overrun will be reduced. Treatments with substituting SMP in 75 or $100 \%$ by dehulled black rice flour exhibited very high viscosity level that the air cells can not be easy to incorporate into the mix during freezing process.

The time required for freezing ice milk samples decreased with dehulled black rice flour to the formula instead of SMP.

The melting resistance given as loss in weight percent from initial weight of the sample is shown in Table (6). The melting resistance decreased with increasing dehulled black rice flour ratio in the ice milk and all functional ice milk formulations with dehulled black rice flour showed higher melting than control. The differences in melting resistance among all ice milk treatments are mainly due to the differences in ratios of added dehulled black rice flour and their effects on mix properties but decreased beyond that with higher substitution ratio 100. Hardness values of ice milk samples revealed a significant increase with adding the dehulled black rice flour to the blend. The highest value of hardness observed in 100\% substitution of SMP. The increase in hardness of ice milk samples with dehulled black rice flour could be attributed to the higher starch contents which may act as stabilizing material and reduce the free water contents, Generally, the hardness values of ice milk are related to several factors such. TS, the freezing point, the amount and type of stabilizer, and thus the free water content, overrun percent and the consistency of the treatment Awad (2007) and Marshall et al., (2003).

\section{The sensory properties}

The sensory panel evaluation is an important indicator of the potential consumer preference. Organoleptic evaluation of ice milk mixes with dehulled black rice flour as a partial substitution of added SMP is shown in Table (7).

The results revealed that addition of dehulled black rice flour in the mixes affected the sensory attributes of ice milk samples. The substitution of SMP up to 25 and $50 \%$ with dehulled black rice flour enhanced sensory attributes of ice milk samples. All organoleptic scores were the highest in case of 50, sample compared to other treatments including control. The improved body and texture of the ice milk 
substituted with 25 and 50 \%dehulled black rice flour. The same trend was observed for the melting properties and colour. That's mean that The ice milk became smoother, slightly less meltable and more acceptable to panelists with incorporating dehulled black rice flour into the formula up to $50 \%$ of added SMP. On the other hand, treatment 100 with $100 \%$ SMP substitution with dehulled black rice flour scored the lowest and was significantly different. Wang et al., (2013) stated that high viscosity means the cream hardly moves within the mouth and it may feel sticky on the palate because of its resistance to movement. However, low viscosity is easy to move within the mouth, and it may be perceived as watery immediately after the cream has liquefied. Our present findings are in accordance with Awad (2007).

Abou Zeid et al., (2015) studied the effect of substituting 0, 25, 50, 75, and $100 \%$ SMP with chickpea dehulled black rice flour on ice milk quality. The authors found that substituting up to $50 \%$ of SMP with chickpea dehulled black rice flour would yield ice milk with the best organoleptic properties without adversely effects.

Table 7. Sensory score of ice milk samples with dehulled black rice flour as a substitute of skim milk powder (SMP).

\begin{tabular}{|l|c|c|c|c|c|}
\hline \multirow{2}{*}{ Property } & \multicolumn{4}{|c|}{ Substitution level (\%) of skim milk powder with dehulled black rice flour } \\
\cline { 2 - 6 } & Control & 25 & 50 & 75 & 100 \\
\hline Flavour (45) & $43.00 \pm 1.00^{\mathrm{a}}$ & $43.25 \pm 0.64^{\mathrm{a}}$ & $43.50 \pm 1.06^{\mathrm{a}}$ & $41.30 \pm 1.24^{\mathrm{b}}$ & $38.70 \pm 1.3^{\mathrm{c}}$ \\
\hline $\begin{array}{l}\text { Body \& } \\
\text { texture } \\
(35)\end{array}$ & $32.0 \pm 1.27^{\mathrm{ab}}$ & $33.0 \pm 1.27^{\mathrm{a}}$ & $33.5 \pm 1.06^{\mathrm{a}}$ & $32.0 \pm 1.41^{\mathrm{ab}}$ & $30.2 \pm 1.64^{\mathrm{b}}$ \\
\hline $\begin{array}{l}\text { Melting } \\
\text { properties } \\
(10)\end{array}$ & $8.3 \pm 0.45^{\mathrm{a}}$ & $8.3 \pm 0.27^{\mathrm{a}}$ & $8.5 \pm 0.61^{\mathrm{a}}$ & $8.15 \pm 0.22^{\mathrm{a}}$ & $7.2 \pm 0.27^{\mathrm{b}}$ \\
\hline \begin{tabular}{l} 
Colour (10) \\
\hline $\begin{array}{l}\text { Total score } \\
(100)\end{array}$
\end{tabular} & $81.55 \pm 2.15^{\mathrm{ab}}$ & $93.05 \pm 1.24^{\mathrm{a}}$ & $94.5 \pm 1.37^{\mathrm{a}}$ & $89.95 \pm 2.09^{\mathrm{b}}$ & $83.6 \pm 2.3^{\mathrm{c}}$ \\
\hline
\end{tabular}

Values are means of three replicates $\pm S D$, numbers in the same raw, followed by the same letters, are not significantly different at 0.05 level.

\section{CONCLUSION}

From the obtained results, it could be concluded that ice milk can be produced as functional food by adding dehulled black rice flour in the base blend of ice milk. Ice milk can be successfully produced with high quality by substituting SMP with dehulled black rice flour up to $50 \%$ without adding stabilizer. Also, dehulled black rice flour adding as natural source of color and antioxidant could improve nutritive and health values of the resultant products. 


\section{REFERENCES}

1. Abdel-Aal, E. S. M.; Young, J. C. and Rahalski, I. 2006. Anthocyanin composition in black blue ,pink,purple, and red cereal grains.J. Agric. and Food Chem.,54:4696-4704

2. Abou Zeid, N.A.; Zedan, A.N.; El-Sisi, A.S. and Ali, A.O.M. 2015. Effect of replacing skim milk powder (SMP) with chickpea flour on ice milk quality. Minufiya J Agric 40:1-14

3. Amiri, H. S.; Nateghi, L. and Berenji, S. 2014. Effect of date syrup as a substitute for Sugar on physicochemical and sensory properties of ice cream. IJB 5:80-88

4. AOAC. 2007. AOAC Official Methods of Analysis, 18th.ed. AOAC, Washington, DC

5. Arbuckle, W. S. 1986. Ice Cream, 4th ed. Avi Publishing Company inc., Westport, CT. Ice cream. AVI Publ. Co., Inc., Westport, CT. 92, 186-187

6. Awad, R.A. 2007. Performance of rice flour in ice cream manufacture. Proc. $10^{\text {th }}$. Egyptian Conf. Dairy Sci. Technol., 517- 534.

7. Cadena, R. S. and Bolini, H. M. A. 2011. Time-intensity analysis and acceptance test for traditional and light vanilla ice cream. Food Res. Int. 44:677-683.

8. Ceirwyn, S. J. 1995. Analytical Chemistry of Foods .Part 1 in book.P.135.

9. FAO (1977). Regional Dairy Development and Training Center for the Near East. Laboratory Manual, Spring, 1977.

10. Fayed, A. E.; Metwally, A. I.; Essawy, E. A. and Meranda, A. T. 2012. Application of ultrafiltration technique in the manufacture of reduced-calorie frozen bioyoghurt in synbiotic form. $11^{\text {th }}$ conf., Agric., Dev., Res., Fac., Agric., Ain Shams Univ., Cairo, Egypt, March. Annals of Agric. Sci., sp. Issue, Vol.,58:315-331.

11. Hankinson, D. J. 1975. Potential source of copper contamination of farm milk supplies measured by Atomic absorption Spectrophotometer .J. Dairy Sci.58:326-336.

12. Kebary, K. M. K. and Hussein, S. A. 1997. Quality of ice cream as influenced by substituting non-fat dry milk with whey-bean proteins coprecipitates. Egyptian J. Dairy Sci. 25: $311-325$.

13. Kong, j. k. and Lee, J. 2010. Antioxidants in milling fractions of black rice cultivars. Food Chemistry ,120:278-281 
14. Li, H.; Prakash, S.; Nicholson, T. M.; Fitzgerald, M. A. and Gilbert, R. G. 2016. The importance of amylose and amylopectin fine structure for textural properties of cooked rice grains. Food Chemistry, 196:702-711

15. Liou, B. K. 2006. Sensory analysis of low fat strawberry ice creams prepared with different flavor chemicals and fat mimetics. Ph.D thesis, Food Sci Dep Fac Graduate School, Univ Missouri-Columbia.

16. Marshall, R. T. and Arbuckle, W. S. 1996. Ice cream 5th ed. Indian diet Prof Int Soyproteinfood conf., Chapman and Hall, Int, Thomson Pub.USA, pp70

17. Marshall, R. T.; Goff, H. D. and Hartel, R.W. 2003. Ice cream.6 th ed .Kluwer Academic Plenum Publisher, NY, USA

18. Olivera, P.; Mila, J. and Mladen, M. 2006. Chemical Composition and Antioxidant Activity of Essential Oils of Twelve Spice Plants. Croatica Chemica Acta, 79:545-552.

19. Richardson, H. G. 1986. Standard methods for the examination of dairy products, $15^{\text {th }}$ edn. Amr. Public Health Assoc, Washington.

20. Segall, K. I. and Goff, H. D. 2002. A modified ice cream processing routine that promotes fat destabilization in the absence of added emulsifier. Inter Dairy J 12:1013-1018.

21. Steel, R. G. D.; Torrie, J. H. and Dickey, D. A. 1997. Principles and Procedures of Statistics. A Biometrical approach. McGraw Hill Book Co., New York, USA.

22. Suzuki, M.; Kimura, T.; Yamagishi, K.; Shinmoto, H. and Yamaki, K. 2004. Comparison of mineral contents in 8 cultivars of pigmented brown rice. Nippon Shokuhin Kagaku Kogaku Kaishi, 51: 424-427.

23. Tarkashvand, Y. 2005. Ice cream. First print. Tehran. Ata publisher (in Persian) C.F. Rezaei et al., 2011.

24. Wang, C.; He, X.; Huang, Q.; Fu, X. and Liu, S. 2013. Physicochemical properties and application of micronized cornstarch in low fat cream. J Food Eng 116:881-888. 


\section{الاستبدال الجزئي للجوامد اللبنية غير الدهنية بدقيق الارز الاسود منزوع القشره في تصنيع المثلج اللبني}

\section{ميراندا عبد المجلي توفيق' ، زهرة العلا محمود محمد محمودّ، ايات ابراهيم رزقَّ}

ا ـ قسم بحوث تكنولوجيا الالبان ، معرة بحوث تكنولوجيا الاغذية ، مركز البحوث الزراعبة ،

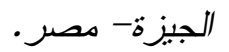

r ـ قسم بحوث تكنولوجيا المحاصيل ، معهد بحوث تكنولوجيا الاغذية ، مركز البحوث الزراعبة ،

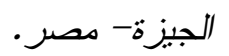

r. قسم بحوث الاغذية الخاصة والتغذيه ، معهد بحوث تكنولوجيا الاغذية ، مركز البحوث

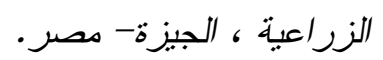

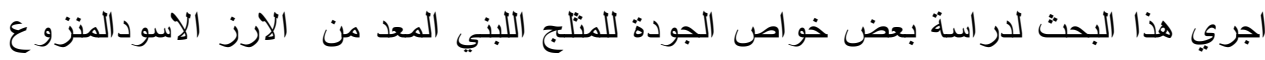

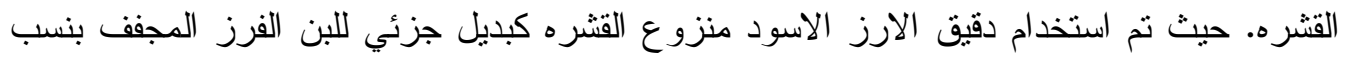

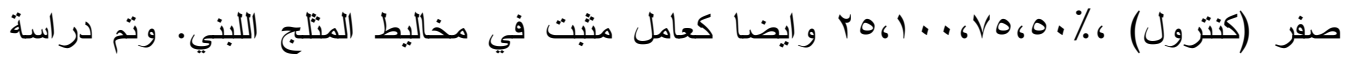
الخو اص الكيماوية و الطبيعية والريولوجية وكذلك الخواص الحسية لكلا من المخاليط و المنلجات

و قد أظهرت النتائج أن الاستبدال للبن الفرز المجفف بدقيق الارز الاسود المنزوع القشره أدي

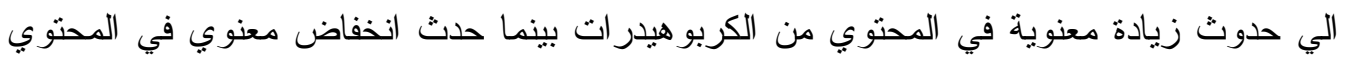
من البروتين و الرماد في مخاليط المنلجات اللبنية. اظهرت النتائج ايضا حدوث اختلافات في قيم الكثافة النوعية نتيجه لنسب الاستبدال لكلا من

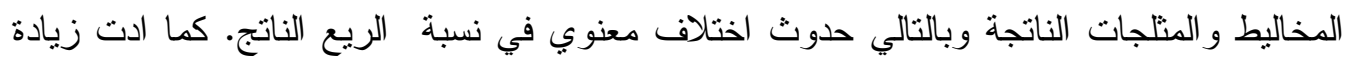
نسبة الاستبدال بدقيق الارز الاسود المنزوع القشره الي زيادة النشاط المضاد للتأكسد للمخاليط.

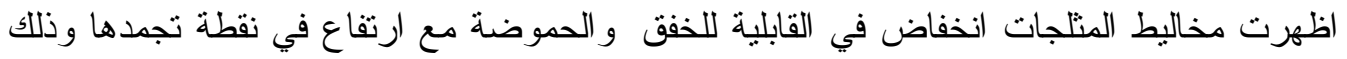
بزيادة نسبة الاستبدال بدقيق الارز الاسود المنزوع القتره ـ ايضا حدوث زيادة معنوية في اللزوجة

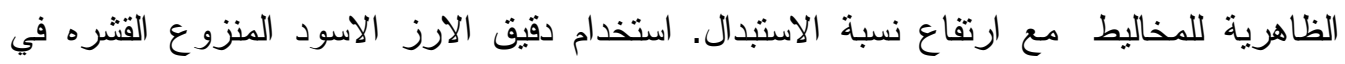
تصنيع المتلج اللبني كان مصحوبا بزيادة في المحتوي من الحديد والزنك و البوتاسيوم. كما ان نسبة النية الاستبدال حتي •\% ادت الي تحسن في الخواص الحسية لعينات المتلج اللبني. 